\title{
Male sex workers in Córdoba, Argentina: sociodemographic characteristics and sex work experiences
}

\author{
Rodrigo Mariño, ${ }^{1}$ Victor Minichiello, ${ }^{1}$ and Carlos Disogra ${ }^{2}$
}

ABSTRACT Objective. To report on the sociodemographic characteristics and work experiences of 31 male sex workers (MSWs) in the city of Córdoba, Argentina.

Methods. Information on each of the MSWs was collected using a questionnaire that covered his personal characteristics and his work background, self-assessed general health status, and use of health and social services. Scales were included in order to assess attitudes towards condom use, knowledge about safe sex, perceptions about the risk of getting HIV, individual self-efficacy, and locus of control. The questionnaire also asked each respondent to rank his level of agreement with interactive strategies for gaining client compliance with safe sex practices.

Results. In terms of their self-identity, out of the $30 \mathrm{MSWs}$ who answered the question, 10 of them (33.3\%) self-identified as heterosexual and $9(30 \%)$ as bisexual. Alcohol and drug consumption and unsafe sexual practices were relatively low among the MSWs. Of the $31 \mathrm{MSWs}$ responding, 21 of them $(67.7 \%)$ reported that they had been tested for HIV, but only 13 of them $(41.9 \%)$ said they had been vaccinated for either hepatitis A or hepatitis B. A variety of differences were found between the study's 17 street sex workers (sex workers who offer their services in public places such as streets and parks) and the 14 independent sex workers (sex workers who are self-employed, advertise and manage their own business, and have an exclusive location for their commercial sex work). The street MSWs were younger and had less formal education. Independent MSWs were economically more settled, had been working longer in the sex industry, and were more comfortable about having sex with men. Independent MSWs were also more likely to report a gay sexual orientation and less likely to report using alcohol, marijuana, or other substances.

Conclusions. The differences between street MSWs and independent MSWs are important since they could influence the negotiating of safer sex practices with clients. Programs aimed at preventing the spread of HIV and other sexually transmitted infections and promoting responsible self-care among MSWs in Córdoba should be introduced. Such programs could increase the proportion of MSWs who know their HIV serostatus and could make MSWs more aware of the risk of different sex acts performed in commercial sex encounters. Given the differences that we found between street MSWs and independent MSWs, specific strategies and educational materials should be developed for those two subgroups within the MSW population.

Key words Prostitution, male homosexuality, HIV, risk factors, Argentina.

1 University of New England, School of Health, Armidale, New South Wales, Australia. Send correspondence to: Rodrigo Mariño, School of Health, University of New England, Armidale, New South Wales, 2351, Australia; telephone: 6126773 3647; fax: 612 6773 3666; e-mail: rmarino@metz.une.edu. au

2 Universidad Nacional de Córdoba, Facultad de Psicología, Córdoba, Argentina.
Sex work is an occupation where a sex worker is hired to provide sexual services for monetary considerations (1). In general, the commercial sex interaction involves the short-term exchange of information, funds, social symbols, and meanings. These interactions are shaped by sociodemographic characteristics, work experiences, norms, knowledge, and other psychosocial factors (2).

A review of studies on male sex workers (MSWs) highlighted several limitations of the existing research on this topic (2). First, most studies 
largely consist of street male sex workers (sex workers who offer their services in public places such as streets and parks), with a lack of recruitment of participants from a broader range of modalities of sex work, such as independent sex workers (sex workers who are self-employed, advertise and manage their own business, and have an exclusive location for their commercial sex work). Second, while this existing knowledge may be useful in developing public health programs, often the data are retrospective, with the researcher having asked respondents just to provide an aggregate picture of their previous sex encounters. This approach fails to recognize that not all encounters are the same and that some encounters have particular qualities about them that result in different levels of rapport, trust, and safety of the outcomes of the sexual encounter.

Minichiello and his colleagues (3-7) are addressing this gap in the literature. They propose an Interactive and Contextual Model (ICM) for analyzing the interaction occurring between MSWs and their clients (8). The ICM is based on four main elements. When applied to a commercial sex interaction, these four elements are: (1) the sexual interaction process, (2) the MSW and client participants, (3) the specific place and time where the commercial sex encounter happens, and (4) the wider environment, including laws, policies, regulations, and cultural norms and values on which sex and the sex industry operate. Minichiello and his colleagues have also proposed a fifth category for the ICM: the outcomes of the commercial sex interaction. There are many outcomes for a sexual encounter, but the main purpose of our efforts in this area is to determine whether the sexual session had safe sex as an outcome or not. This ICM provides the framework for this study, which maps out a descriptive profile of male sex workers in the city of Córdoba, Argentina.

The scientific literature on the sociodemographic characteristics and work experiences of MSWs has been growing over the past decade (2). Large-scale surveys and HIV prevalence and incidence studies of male sex workers have been conducted in Australia $(4,6,9,10)$,
Canada (11), the United States of America $(12,13)$, the United Kingdom (14), Thailand (15), the Netherlands $(16,17)$, Spain (18), New Zealand (19), and Indonesia (20). More recently, efforts to prevent infection by HIV and other sexually transmitted infections (STIs) among MSWs have been reported in the United States (21) and the United Kingdom (22). In Latin America, studies have been conducted in Brazil (23-26), Mexico (27), the Dominican Republic (28), Costa Rica $(29,30)$, and Peru (31). In Argentina, with the exception of a study on MSWs in Buenos Aires in the 1980s (32) and a case report published in 2000 (33), limited information exists about MSWs, even though the worldwide HIV/AIDS crisis affects Argentina as well.

As part of a broader effort aimed at studying male sex work in Argentina and determining the feasibility of undertaking a cross-national study on male sex work, this paper will provide information on sociodemographic variables and sex work characteristics of male sex workers from Córdoba, Argentina. This study is seen as a necessary first step to inform the design of studies on sex workers as well as to further studies that undertake crossnational comparisons.

A federal republic, Argentina had a population of 37.5 million people as of 2001 (34). The capital, Buenos Aires, has a population of some 11 million. Córdoba is the second largest city in the country and is the capital of the province of the same name. In 2001 the city of Córdoba had a population of 1.2 million (35).

Prostitution is legal in Argentina, but offering sex services in the street is an offense, for which a local court, at its discretion, may impose a sentence (generally of a few days in jail), a fine, or both (36). Additionally, "pimping," or encouraging prostitution, is illegal (36). Although homosexuality is not an offense in Argentina, there are reports of discrimination against persons who are gay or HIV-positive $(33,37)$.

All the main types of MSWs are found in Argentina, including in Córdoba: independent MSWs, MSWs who work in or through agencies, and street MSWs. Large cities, including Córdoba, generally also have a well-delim- ited "red light" district where street male sex workers offer their services.

In Argentina there are several organizations concerned with the prevention of HIV transmission, and in Buenos Aires there is a female sex workers' union. However, there are no Government-funded sex worker organizations or community groups with a mandate to, for example, offer services to sex workers, such as specific health promotion or peer education programs. In large part, such health promotion efforts are carried out by volunteers working in local-level organizations, including human rights groups and gay organizations. This lack of support for MSW health promotion and education may be especially critical in Córdoba, where preventive behavior among men who have sex with men is less prevalent than in other cities in Argentina, according to one comparative study (38).

The estimated number of people living with HIV in Argentina at the end of 2001 was 130000 (39). Over the past decade the male-female ratio of HIV infections has declined, falling from 4.1:1.0 in 1992 to 2.9:1.0 in $2002(34,40)$. The prevalence of other STIs, including syphilis and gonorrhea, remained relatively stable between 1991 and 2000 (34).

\section{MATERIAL AND METHODS}

\section{Recruitment of male sex workers}

The inclusion criteria for the selection of respondents for this study were men aged 18 years and older currently working as male sex workers and offering their sexual services to other men. The planning of the recruitment strategy commenced with estimating the size of the pool of potential participants by assessing how many street, independent, and agency workers were working on any particular day in Córdoba. The recruiting strategy for the different categories of MSWs was modeled after an Australian study on MSWs (4), and it was developed in consultation with a researcher who also acted as the field research coordinator (FRC) in Córdoba for this project. This researcher and co-author (CD) is a psy- 
chologist from the National University of Córdoba who is knowledgeable about the male sex work industry in Córdoba and elsewhere in Argentina.

Different sampling strategies and methods were required to recruit participants in the different sex work modalities. For the independent male sex workers (IMSWs), a list of potential participants was compiled by reviewing the local media where male sex workers advertise. These included $\mathrm{La}$ voz del interior, which is Córdoba's largest daily newspaper, and a chat room for Córdoba that is part of an international Internet site for gay and lesbian persons (http://www.gay.com). Performed between September and December 1999, this preparatory census revealed that there were then 70 IMSWs in Córdoba advertising their services in the print or electronic media. We planned to contact members of this group of MSWs by telephone.

For male sex workers working in or through an agency, a preliminary survey in the La voz del interior newspaper performed in August 1999 revealed that one agency advertised male-to-male commercial sex in Córdoba. We planned to contact this group of MSWs directly or through the management of the agency. We estimated that up to 10 men worked in this modality of MSW.

For street workers (SMSWs), convenience sampling was used, recruiting the men from the area of the city where they work, which is known as la 42 or la zona. The total number of SMSWs in Córdoba is difficult to assess with any accuracy, but we estimated that there were approximately 25 of them at the time of our study.

We estimated our total sample size based on our census survey of how many workers were working on the street, working independently, or working through an agency. Previous work (6) suggested that our response rates would vary according to the modality of sex work. Accordingly, for the three modalities of sex work in Córdoba we established a conservative lower response estimate of $30 \%$ and a maximum upper response estimate of $50 \%$, and we set between 32 and 45 MSWs as the sample target. By modality of work, we anticipated that between 9 and 13 par- ticipants would be street male sex workers, between 3 and 5 participants would be agency workers, and between 20 and 27 participants would be independent male sex workers.

The FRC was responsible for the recruitment plan and the collection of data, including contacting and providing information about the project to the workers and to agency owners. At the first contact with potential MSW participants, the FRC introduced himself and the project, explained the aims of the study, and described what type of participation was required. Study participants received between US $\$ 40$ and US\$ 60 for their time and for their transportation costs for going to a meeting with the FRC. After an MSW agreed to participate in the project, a convenient time to discuss the research instruments was arranged.

\section{Data-collection instruments}

Data were collected using a selfcompletion questionnaire and a diary that each MSW had to complete after each encounter with a client during his respective two-week diary period. The questionnaire covered the personal characteristics of the sex worker as well as his work background, self-assessed general health status, and use of health and social services. In addition, a number of previously validated scales were included in order to assess attitudes towards condom use (41), knowledge about safe sex (42), perceptions about the risk of getting HIV (43), individual self-efficacy (44), and locus of control (45). The instrument also included a validated scale that asked each respondent to rank his level of agreement with 18 interactive strategies to gain client compliance with safe sex practices $(3,7)$. This was done by presenting a series of hypothetical situations describing approaches that sex workers use to get clients to practice safe sex and then asking the respondent how he would act in each of the situations. The diary was used to overcome some of the methodological shortcomings identified with the use of retrospective methods, such as questionnaires or in-depth interviews, and to provide a more detailed physical and psychological context for the commercial sexual transactions between the sex workers and clients (9). In this article we only present results based on the responses to the questionnaire. We plan to report the results from the diaries in future articles.

Approval for the study came from the Ethics and Research Committee of the University of New England and the School of Psychology of the National University of Córdoba.

\section{Data analysis}

The questionnaire items dealt with seven sociodemographic variables, as described below.

The first sociodemographic variable, sexual orientation, was defined in terms of the individual's definition of his sexuality. Respondents were asked to identify themselves as "straight," "bisexual," "gay," or "other" (13).

Relationship status (in personal life, outside of the sex work) was grouped as: "none at present," "casual sex only," "regular relationship, plus I have casual sex," "monogamous relationship," and "other." Those in a permanent relationship were further asked about the gender of their partner.

The living arrangement variable had seven categories in the original questionnaire. We later reclassified the responses into five groups: "renting shared home with flatmate (apartmentmate)," "renting alone," "own my place," "living with parents," and "others," which included "living with friends" and "homeless."

Participants were classified according to their educational level using the following categories: primary education, incomplete secondary education, secondary education, and tertiary education.

While the questionnaire did not include an item on the specific income level, economic need was assessed by asking participants about their financial situation, in terms of: "cannot make ends meet," "can manage to get by," "can manage, plus save," or "do not have money problems."

Individuals were asked whether they had been tested for HIV. Those who answered "yes" were asked to state the period since the last test and 
also to self-report their HIV serostatus results as follows: "positive," "negative," "never went back for results," or "do not know."

The last of the seven sociodemographic variables was age.

In addition to these seven sociodemographic variables, participants were asked about consuming alcohol or other substances, using a list that included alcohol, tobacco, marijuana, heroin, methadone, cocaine, ecstasy, painkillers, and benzodiazepines. They were asked to indicate the frequency of use for each substance consumed, utilizing a 5-point scale for a range that went from "never" to "daily."

The questionnaire also asked about 10 sex work experience variables. The first of the 10 variables was the modality of sex work, categorized as street, agency, and independent. The second variable, length of time working as an MSW, had five categories: "less than 6 months," "between 6 months and 1 year," "between 1 year and 2 years," "between 2 years and 5 years," and "more than 5 years."

Third, participants were asked to tell, from a list of nine alternatives, their main reason for doing sex work. Next, occupational status was characterized according to the following groups: "full-time," "part-time," "occasional," "week-end sex worker," or "when I feel like it." Fifth, participants were asked to indicate, using a "yes" or "no" answer, if they had other sources of income besides sex work.

The sixth category, stress in sex work, was coded as "not at all," "a little stressful," "stressful," and "very stressful." The seventh category, feeling good about being a sex worker was classified as "always," "usually," "sometimes," "rarely," and "never." Participants were next asked about their level of comfort with having sex with men.

For the ninth category, participants were asked whether they had worked as a sex worker in other places in Argentina or in other countries. For the last of the 10 sex work experience variables, participants were asked to review a list of sexual activities and to indicate the sexual acts that they were willing to provide for clients.

In our analysis we compared the results between and the distribution of the sociodemographic variables and the sex work variables. To evaluate the relationship of modality of work with interval data, analyses of variance were conducted. Categorical data and ordinal data were analyzed utilizing chi-square $\left(\chi^{2}\right)$ analysis. However, in some cases, since only a small number of MSWs appeared in some of the categories, no further statistical comparisons could be preformed. Data manipulation and analyses were done using SPSS PC version 10.1 computer software (SPSS Inc., Chicago, Illinois, United States).

\section{RESULTS}

Data collection occurred from midJanuary 2001 to mid-December 2001. A total of $47 \mathrm{MSW}$ were contacted. Of those 47, 35 of them agreed to participate. Reasons for nonparticipation included lack of time and suspicion about the confidentiality of the data provided. A third reason, fear of being caught with the diary by the family, was particularly true for those working as SMSWs.

Of the 35 MSWs who agreed to participate, 4 of them had to be excluded: 3 were under the age of 18 , and 1 worked exclusively in the male-tofemale sex industry.

Of the 31 eligible MSWs who returned the questionnaire, 17 of them worked as street sex workers and 14 worked as independent sex workers. Attempts were made to include agency MSWs, but none could be recruited.

The sociodemographic characteristics of the 31 participants are summarized in Table 1. (In some cases the respective groups in Table 1 total to less than 14, 17 , or 31 because some participants did not answer all of the questions.)

\section{Sociodemographic profile of sex workers}

Age. The age of the respondents ranged from 18 to 37 years old. The mean age was 25.1 years. Table 1 shows the MSWs classified by age groups. The single largest group of MSWs were between 18 and 21 years old. Those working as street sex workers were significantly younger (mean age of 21.7 years) than those working as independent MSWs (mean age of 29.3 years $)\left(F_{1,29}=20.82 ; P<0.001\right)$.

Education, economic need, and living arrangements. With regards to education level, $45.2 \%$ of the MSWs overall had completed at least secondary education (Table 1). However, by type of work, street sex workers had completed much lower levels of education than had independent sex workers. These differences in level of education reached statistical significance $\left(\chi^{2}=\right.$ 8.51; $P<0.02$, degrees of freedom $=2$ ).

In terms of income, 24 of the 31 MSWs (77.4\%) said they could "only manage to get by," and $3(9.7 \%)$ reported that they did not have enough income to cover economic necessities. Another 3 (9.7\%) indicated that they "could manage plus save some money," and 1 MSW (3.2\%) had "no money problems." Street MSWs (3 of 17, or $17.6 \%$ ) were more likely to report that they could not manage to get by than were independent MSWs.

A majority of the MSWs were either renting accommodation (with apartmentmates or alone) or living with their parents ( 10 of 31 , or $32.3 \%$, and 7 of 31 , or $22.6 \%$, respectively). The remainder either owned their own place or had other living arrangements. No MSWs reported being homeless. Street sex workers more likely to live with their parents ( 9 of 17 , or $52.9 \%$ ) than were IMSWs. Independent sex workers were more likely to live in rented accommodations (9 of 14 , or $64.3 \%$ ) than were street sex workers.

Self-identification and relationships. When describing their sexual identity, the most frequent answer from the MSWs was "heterosexual (straight)," closely followed by "gay" (Table 1).

About two-thirds of the sample (20 of 31 , or $64.5 \%$ ) were currently involved in a permanent sexual relationship in their private lives. Of those 20, 15 of them of them were in a relationship with another man, and 5 reported being in a relationship with a female partner.

Alcohol and drug consumption. The substances most frequently consumed were tobacco, alcohol, and marijuana. 
TABLE 1. Distribution of selected sociodemographic characteristics and sex work experiences of 31 male sex workers (MSWs) in the city of Córdoba, Argentina, 2001

\begin{tabular}{|c|c|c|c|c|c|c|}
\hline \multirow{2}{*}{$\begin{array}{l}\text { Sociodemographic characteristics } \\
\text { and sex work experiences }\end{array}$} & \multicolumn{2}{|c|}{$\begin{array}{l}\text { Street sex workers } \\
\qquad(n=17)\end{array}$} & \multicolumn{2}{|c|}{$\begin{array}{l}\text { Independent sex workers } \\
\qquad(n=14)\end{array}$} & \multicolumn{2}{|c|}{$\begin{array}{c}\text { Total } \\
(n=31)\end{array}$} \\
\hline & No. & $\%$ & No. & $\%$ & No. & $\%$ \\
\hline \multicolumn{7}{|l|}{ Age group } \\
\hline 21 and younger & 11 & 64.7 & 1 & 7.1 & 12 & 38.7 \\
\hline 22 to 25 years old & 4 & 23.5 & 3 & 21.4 & 7 & 22.6 \\
\hline 26 to 30 years old & 1 & 5.9 & 4 & 28.6 & 5 & 16.1 \\
\hline Older than 30 years old & 1 & 5.9 & 6 & 42.9 & 7 & 22.6 \\
\hline \multicolumn{7}{|l|}{ Education } \\
\hline Primary education & 4 & 23.5 & 1 & 7.1 & 5 & 16.1 \\
\hline Incomplete secondary education & 9 & 52.9 & 3 & 21.4 & 12 & 38.7 \\
\hline Secondary education & 2 & 11.8 & 2 & 14.3 & 4 & 12.9 \\
\hline Tertiary education & 2 & 11.8 & 8 & 57.2 & 10 & 32.3 \\
\hline \multicolumn{7}{|l|}{ Sexual identification } \\
\hline Straight & 5 & 29.4 & 5 & 38.4 & 10 & 33.3 \\
\hline Bisexual & 4 & 23.5 & 2 & 15.4 & 6 & 20.0 \\
\hline Gay & 3 & 17.7 & 6 & 46.2 & 9 & 30.0 \\
\hline Other (do not know/unsure) & 5 & 29.4 & 0 & 0.0 & 5 & 16.7 \\
\hline \multicolumn{7}{|l|}{ Length of time as MSW } \\
\hline Less than 6 mo & 2 & 11.8 & 2 & 14.3 & 4 & 12.8 \\
\hline Between $6 \mathrm{mo}$ and I yr & 2 & 11.8 & 4 & 28.6 & 6 & 19.4 \\
\hline Between I yr and $2 \mathrm{yr}$ & 6 & 35.2 & 0 & 0.0 & 6 & 19.4 \\
\hline Between $2 \mathrm{yr}$ and $5 \mathrm{yr}$ & 5 & 29.4 & 5 & 35.7 & 10 & 32.3 \\
\hline More than $5 \mathrm{yr}$ & 2 & 11.8 & 3 & 21.4 & 5 & 16.1 \\
\hline \multicolumn{7}{|l|}{ Basis of work } \\
\hline Full-time & 0 & 0.0 & 7 & 53.8 & 7 & 23.3 \\
\hline Part-time & 1 & 5.9 & 3 & 23.1 & 4 & 13.3 \\
\hline Occasional & 5 & 29.4 & 0 & 0.0 & 5 & 16.7 \\
\hline Weekends only & 2 & 11.8 & 3 & 23.1 & 5 & 16.7 \\
\hline When I feel like it & 9 & 52.9 & 0 & 0.0 & 9 & 30.0 \\
\hline \multicolumn{7}{|l|}{ Feeling good about being an MSW } \\
\hline Always & 0 & 0.0 & 1 & 7.1 & 1 & 3.2 \\
\hline Usually & 3 & 17.6 & 1 & 7.1 & 4 & 12.9 \\
\hline Sometimes & 6 & 35.3 & 5 & 35.7 & 11 & 35.5 \\
\hline Rarely & 2 & 11.8 & 4 & 28.6 & 6 & 19.4 \\
\hline Never & 6 & 35.3 & 3 & 21.5 & 9 & 29.0 \\
\hline \multicolumn{7}{|l|}{ Stress in work } \\
\hline Not at all & 4 & 23.5 & 1 & 7.2 & 5 & 16.1 \\
\hline A little & 7 & 41.2 & 10 & 71.3 & 17 & 54.8 \\
\hline Stressful & 1 & 5.9 & 1 & 7.2 & 2 & 6.5 \\
\hline Very stressful & 5 & 29.4 & 2 & 14.3 & 7 & 22.6 \\
\hline \multicolumn{7}{|l|}{ Comfortable with having sex with men } \\
\hline Very comfortable/Comfortable & 5 & 29.4 & 7 & 58.2 & 12 & 41.4 \\
\hline Neither comfortable nor uncomfortable & 4 & 23.5 & 3 & 25.0 & 7 & 24.1 \\
\hline Uncomfortable/Very uncomfortable & 6 & 35.3 & 1 & 8.4 & 7 & 24.1 \\
\hline Do not know/Unsure & 2 & 11.8 & 1 & 8.4 & 3 & 10.4 \\
\hline
\end{tabular}

a In some cases the respective groups total to less than 17, 14, or 31 because some participants did not answer all of the questions. The percentage values shown were calculated based on the number of persons who answered the particular question.

About two-thirds of the MSWs (20 of 31 , or $64.5 \%$ ) reported daily use of tobacco, and about half of the sample (16 of 30 , or $53.3 \%$ ) reported drinking alcohol at least once a week, including 1 MSW who indicated that he drank daily. Regarding use of marijuana, 5 of $29(17.2 \%)$ reported using it at least once a week, and 2 indicated daily use.

None of the participants reported using heroin, speed, or methadone. Among the drugs that respondents did mention using were cocaine (4 of 28 respondents), benzodiazepines ( 3 of 28 ), painkillers (1 of 28), and ecstasy (1 of 28). The workers who used these drugs were all street workers, but only one reported using them more than once a week; he reported using cocaine on a daily basis. Only SMSWs reported use of marijuana. On the other hand, IMSWs did not report consumption of any substances besides alcohol and tobacco.
We found that street MSWs were significantly more likely $(P<0.02)$ to consume tobacco or alcohol than were independent MSWs when we grouped usage as "never" versus all the other usage-frequency categories. On the other hand, only 6 of 31 of the participants $(19.4 \%)$ reported polysubstance use, defined as the use of more than one of the listed substances (excluding tobacco) at least once a week, and all those 6 were working as SMSWs. 
Sexually transmitted infections, HIV testing, and serostatus. When asked whether they had been checked for STIs, 25 of 30 respondents (83.3\%) said they had been. Among these 25, 4 $(16.0 \%)$ reported having had the test in the 4 weeks before the survey, $8(32.0 \%)$ within the preceding 1 to 6 months, $4(16.0 \%)$ between 6 and 12 months earlier, and $9(36.0 \%)$ more than a year earlier. Of the 25 who had been checked, 2 of them $(8.0 \%)$ reported a positive result. One participant had never checked his results.

Participants were also asked whether they had been vaccinated against hepatitis A or hepatitis B, or both. Of the 31 MSWs, 18 of them (58.1\%) said that they had not been vaccinated or that they were not sure, $9(29.0 \%)$ said they had been vaccinated for both hepatitis $A$ and hepatitis B, 2 (6.5\%) said they had received only a hepatitis A vaccination, and another $2(6.5 \%)$ said they had received only a hepatitis B vaccination.

Regarding HIV status, 21 of 31 MSWs (67.7\%) said they had had an HIV antibody test. Among those 21 who were tested, 3 of them $(14.3 \%)$ had had the test within the 4 weeks before the survey, 9 of them $(42.9 \%)$ had had the test between 1 and 6 months prior to completing the questionnaire, $2(9.5 \%)$ had had the test between 6 and 12 months earlier, and $7(33.3 \%)$ had had the test more than a year before. Of those who had their results at the time of the survey, all reported a negative result.

\section{Sex work experiences}

The single most frequent period working as a sex worker was 2 to 5 years (Table 1). By modality of work, IMSWs tended to have been working longer in the sex industry. For example, $57.1 \%$ of the IMSWs had worked in the industry for more than 2 years, compared to $41.1 \%$ of the SMSWs.

Of the 31 MSWs, 11 of them (35.5\%) said they had worked as an MSW in places other than Córdoba. Most mentioned either the city or province of Buenos Aires. Four participants indicated that they had worked in some other country, including Brazil and the United States.
Slightly fewer than half of the workers said they worked either when they "feel like it" or occasionally (Table 1). Just under one-quarter worked fulltime as sex workers. By modality of sex work, just over half of the IMSWs worked full-time, while just over half of the SMSWs did it when they "feel like it."

For 19 of 31 of the participants $(61.3 \%)$, sex work was the only source of income. However, this was true for 11 of the 14 IMSW respondents $(78.6 \%)$.

In response to the question about their main reason for working in the sex industry, 15 of 28 respondents (53.7\%) said it was the lack of other work opportunities. The next most frequent reasons given were money (7 of 28 , or $25 \%$ ) and chance ( 3 of 28 , or $10.7 \%$ ).

The male sex workers reported a variety of sex practices that they were willing to engage in as part of their sex work, from highly unsafe sexual acts to activities that do not involve intimate contact, such as watching videos and dirty talking. All the MSWs were willing to practice insertive anal sex with a condom or to watch videos with clients. Most MSWs (25 of 31, or $80.6 \%$ ) were willing to practice selfmasturbation. Receptive masturbation was mentioned by 30 of 31 MSWs $(96.8 \%)$, and mutual masturbation was listed by 19 of 31 (61.3\%). Two other sexual acts frequently mentioned were erotic massage (18 of 31 , or $58.1 \%$ ) and body rubbing (17 of 31 , or $54.8 \%$ ). Insertive anal sex without a condom was mentioned by 3 participants (9.7\%). None of the MSWs was willing to perform receptive anal sex without a condom. However, receptive anal sex with a condom was mentioned by 12 of 31 of the MSWs (38.7\%). Insertive fisting (i.e., penetration of the anal cavity with the fist) was mentioned by 10 of 31 MSWs (32.2\%). One MSW (3.2\%) reported being willing to perform receptive fisting. Six of 31 MSWs (19.4\%) reported being willing to perform active rimming (i.e., oral-anal sex). A higher proportion were willing to perform receptive rimming (11 of 31 , or $35.5 \%$ ). A little more than half of the MSWs (18 of 31 , or $58.1 \%$ ) were willing to perform insertive oral sex without a condom to the point of orgasm. Receptive oral sex to the point of orgasm without a condom was mentioned by 1 MSW (3.2\%).

A little fewer than one-third of the participants reported that they "never" felt good about being a MSW, and just under 20\% "rarely" felt good about being a sex worker (Table 1). Only about one in six said they "usually" or "always" felt good about being a MSW.

A slight majority of the participants reported sex work as "a little stressful," with the next largest group saying it was "very stressful" (Table 1). Only about one in six characterized the sex work as "not at all stressful." Although the difference was not statistically significant, there was a trend among street MSWs to report feeling more stressed about sex work than independent MSWs did.

The participants were also asked about their degree of comfort with having sex with males. The single largest group of participants reported feeling comfortable or very comfortable with having sex with men (Table 1). About one-quarter felt uncomfortable or very uncomfortable with having sex with men. By modality of sex work, there was a trend among SMSWs to feel more uncomfortable with having sex with men than IMSWs did.

\section{DISCUSSION}

The sample size in Córdoba was at the low end of the expected number. Nevertheless, we found the MSWs there to be an approachable and researchable population, which is similar to the experience in some other countries $(4,9,46)$.

As in another report on MSWs (6), differences between modalities of sex work emerged. Street MSWs in Córdoba were younger, less educated, and more likely to be living with their parents than were independent MSWs. In comparison to street MSWs, independent MSWs were economically more settled, had been working longer in the sex industry, and were more comfortable about having sex with men. IMSWs were also more likely to report a gay sexual orientation and less likely to report use of alcohol, marijuana, and other substances. It was not clear 
whether being an SMSW is a transitional stage to becoming an IMSW or if these two modalities represent different populations with a distinctive occupational path. The profile differences found in Córdoba extend our knowledge of sex work and sexuality among men in different countries. Such profile differences are of importance since they may influence the commercial transaction with regard to negotiating safer sex outcomes with clients (9).

It has been argued that utilizing selfreported data on sensitive topics, such as sex and drug use, always carries the risk of obtaining socially desirable answers (47). For example, in the Córdoba sample of MSWs, some twothirds said they had been tested for HIV. None of the participants reported an HIV-positive serostatus. These selfreported HIV testing and status results could be questioned because of a possible tendency to underreport conditions that are socially unacceptable (48). However, Minichiello et al. (6) found a self-reported HIV prevalence of $6.6 \%$ among Australian MSWs from Brisbane, Melbourne, and Sydney. Estcourt et al. (10) reported a similar seroprevalence rate, $6.7 \%$, using serologic testing in MSWs from Sydney, thus indicating the validity of the selfreported HIV status among MSWs.

Few of the MSWs in Córdoba reported high levels of drug and alcohol consumption, and none of them reported intravenous drug use. Although this may well be due to underreporting, low alcohol and drug consumption has also been reported among MSWs in Australia (6) and in the United Kingdom (14). These results suggest that MSWs are acting professionally and responsibly with regards to drug use and safer sex activities during the commercial interaction with clients, and education campaigns need to increase or continue to reinforce the professionalism of such behavior in the sex industry.

Regarding HIV testing in Córdoba, 14 of the 31 MSWs (45.1\%) reported having had an HIV test within the preceding 12 months. Although this highlights an area in need of improvement in the provision of services and public health support, it also reflects current levels of knowledge and of access to testing. With respect to hepatitis, there was a generally low level of vaccination, which could be due to the lack of knowledge about their occupational risk of exposure.

In this study, participants reported the sex acts that they would be willing to perform with a client, but we acknowledge that the self-reported list does not necessarily reflect what the MSWs actually do with their clients. Overall, the MSWs seemed to be aware of the risk of transmitting HIV and other STIs in these sexual acts. However, it was obvious that the MSWs were willing to practice insertive anal sex and, to a lesser extent, receptive anal sex. Both practices have been described as having the highest risk of HIV transmission. Additionally, a significant number were willing to perform sexual activities that involve high risk of transmission of hepatitis, but not HIV, such as rimming.

Most of the MSWs in our Córdoba study entered the profession due to the general lack of job opportunities and of money. One could assume that under those circumstances clients would be able to exert more control over the interaction. A strong association has been found between who is in control of the commercial sex interaction and the safety of the sex outcome $(4,18)$. However, it has been demonstrated that safe-sex negotiating and communications skills can be learned (14). Sexual health clinics and sex work organizations are good venues for educating and supporting safer sex practices in the sex industry (7).

The Córdoba study had some interesting results relating to sexual selfidentification, stress, and feelings about sex work and having sex with men. For example, among the street MSWs in Córdoba, fewer than a third of them felt "very comfortable" or "comfortable" having sex with men. Particularly as it affects the lives of young males, the long-term consequences of such selfperceptions are poorly understood.

It is important to emphasize that the results from Córdoba cannot be extrapolated to the rest of Argentina or to other Latin American nations. This underscores the need for further research on male sex workers.
With regard to MSWs, Argentina is different from at least some other countries in Latin America. For example, when the field research coordinator was visiting places in Córdoba where independent MSWs offer their services, he did not find the unhygienic working conditions that Schifter (29) reported for a brothel in Costa Rica. Furthermore, most of the MSWs from Córdoba had at least some secondary education. This contrasts with reports of illiteracy among SMSWs from Rio de Janeiro, Brazil, and low levels of education in San José, Costa Rica (24-26, 29). Although our Córdoba study was constrained by having to recruit only respondents 18 years or older, the FRC did not find the underage situation described for the Costa Rica brothel (29). However, similar to Córdoba, the MSWs in that brothel mentioned the lack of job opportunities as a reason for working in the sex industry.

Although prostitution is legal in Argentina, there are no MSW organizations or community groups that run health promotion or peer education programs among male sex workers. The Government's national agency for the control of AIDS and STIs has funded only one project for health promotion and education among MSWs, in Buenos Aires (49). This is in spite of the fact that research elsewhere has indicated that having STI/HIV health education efforts sponsored by the State is an effective means of educating MSWs and promoting safe sex strategies and behaviors (4).

Our results suggest that programs that are aimed at preventing the spread of HIV and other STIs and promoting responsible self-care among MSWs in Córdoba should be introduced. Such programs might, for example, increase the proportion of MSWs who know their HIV serostatus, or make MSWs more aware of the risk of the different sex acts performed in commercial sex encounters. Given the differences that we found between street MSWs and independent MSWs, specific strategies and materials should be developed for those two subgroups within the MSW population. These may range from printed pieces promoting safer sex as a means of preventing the transmission of STIs to 
highly coordinated community projects that employ workers who are familiar with the social context in which MSWs operate and who provide the MSWs with peer education, a support network, and other essential social services. Future efforts should also focus on creative strategies to reach MSWs who might face higher risk because they are isolated from peer education and other forms of support. Additional efforts are also needed to determine the influence that both specific legislation and the overall policy context have on how MSWs enter the sex industry and on these men's attitudes toward being sex workers.

\section{REFERENCES}

1. Visano L. Generic and generative dimensions of interactionism: towards the unfolding of critical directions. Int Jour Comp Soc 1988; XXIX(3-4):230-243.

2. Minichiello V, Mariño R, Browne J, Jamieson M. A review of male to male commercial sex encounters. Venereology 1998;11(4):32-42.

3. Browne J, Minichiello V. The social meanings behind male sex work: implications for sexual interactions. Br J Sociol 1995;46(4):598-622.

4. Minichiello V, Mariño R, Browne J, Jamieson M, Peterson K, Reuter B, et al. A profile of clients of male sex workers in three Australian cities. Aust NZ J Public Health 1999;23(15): 65-72.

5. Minichiello V, Mariño R, Browne J. Knowledge, risk perceptions and condom usage in male sex workers from three Australian cities. AIDS Care 2001;13(3):387-402.

6. Minichiello V, Mariño R, Browne J, Jamieson M, Peterson K, Reuter B, et al. Male sex workers in three Australian cities: sociodemographic and sex work characteristics. J Homosex 2002;43(1):29-51.

7. Mariño R, Browne J, Minichiello V. An instrument to measure safe-sex strategies used by male sex workers. Arch Sex Behav 2000;29(3): 217-228.

8. Hakansson H. Technological innovation through interaction. In: Hakansson H, ed. Industrial technological development: an interaction approach. London: Croom Helm; 1987. Pp. 3-25.

9. Minichiello V, Mariño R, Browne J, Jamieson M. Commercial sex between men: a prospective diary based study. J Sex Res 2000;37(2): 151-160.

10. Estcourt CS, Marks C, Rohrsheim R, Johnson AM, Donovan B, Mindel A. HIV, sexually transmitted infections, and risk behaviours in male commercial sex workers in Sydney. Sex Trans Inf 2000;76(4):294-308.

11. Weber AE, Craib KJ, Chan K, Martindale S, Miller ML, Schechter MT, et al. Sex trade involvement and rates of human immunodeficiency virus positivity among young gay and bisexual men. Int J Epidemiol 2001;30(6):14491454.

12. Elifson KW, Boles J, Sweat M. Risk factors associated with HIV infection among male prostitutes. Am J Public Health 1993;83(1):7983.

13. Simon PM, Morse EV, Osofsky HJ, Balson PM. HIV and young male street prostitutes: a brief report. J Adolesc 1994;17:193-197.
14. Bloor MJ, Barnard MA, Finlay A, McKeganey NP. HIV-related risk practices among Glasgow male prostitutes: reframing concepts of risk behavior. Med Anthropol Q 1993;7(2): 152-169.

15. Kunawararak $P$, Beyrer $C$, Natpratan $C$, Feng $\mathrm{W}$, Celentaro DD, Boer M, et al. The epidemiology of HIV and syphilis among male commercial sex workers in Northern Thailand. AIDS 1995;9(5):517-521.

16. De Graaf R, Vanwesenbeeck I, van Zessen G, Straver $\mathrm{CJ}$, Visser JH. Male prostitutes and safe sex: different settings, different risks. AIDS Care 1994;6(3):277-288.

17. De Graaf R, Vanwesenbeeck I, van Zessen G, Straver CJ, Visser JH. Alcohol and drug use in heterosexual and homosexual prostitution, and its relation to protection behaviour. AIDS Care 1995;7(1):35-47.

18. Belza MJ, Llacer A, Mora R, Morales M, Castilla J, de la Fluent L. Sociodemographic characteristics and HIV behaviour patterns of male sex workers in Madrid, Spain. AIDS Care 2001;13(5):677-682.

19. Weinberg MS, Worth H, Williams CJ. Men sex workers and other men who have sex with men: how do their HIV risks compare in New Zealand? Arch Sex Behav 2001;30(3): 273-286.

20. Ford K, Wirawan DN, Fajans P. AIDS knowledge, condom beliefs and sexual behaviour among male sex workers and male tourist clients in Bali, Indonesia. Health Transit Rev 1993;3(2):191-204.

21. Miller RL, Klotz D, Eckholdt HM. HIV prehustler bars: replication of an HIV preventive intervention. Am J Community Psychol 1998; 26(1):97-131.

22. Ziersch A, Gaffney J, Tomlinson DR. STI prevention and the male sex industry in London: evaluating a pilot peer education programme. Sex Transm Infect 2000;76(7):447-453.

23. Perlongher NO. El negocio del deseo. La prostitución masculina en San Pablo. Buenos Aires: Paidós Press; 1999.

24. Parker R, Larvie P, Cardoso R. Programa Pegação: an outreach program for male commercial sex workers in Rio de Janeiro. In: Bond LS, ed. A portfolio of AIDS/STD behavioral interventions and research. Washington, D.C.: Pan American Health Organization; 1992. Pp. 171-178.

25. Longo PH. Michê. Rio de Janeiro, Brazil: Planeta Gay Books; 1998. vention with male prostitutes and patrons of
Acknowledgments. This study was funded by grants from the Australian Research Council (ARC) and the Secretary of Science and Technology of the Universidad Nacional de Córdoba, Argentina.
26. Larvie P. Natural born targets: male hustlers and AIDS prevention in urban Brazil. In: Aggleton $\mathrm{P}$, ed. Men who sell sex: international perspectives on male prostitution and HIV/ AIDS. Philadelphia: Temple University Press; 1999. Pp. 159-178.

27. Liguori AL, Aggleton P. Aspects of male sex work in Mexico City. In: Aggleton P, ed. Men who sell sex: international perspectives on male prostitution and HIV/AIDS. Philadelphia: Temple University Press; 1999. Pp. 103- 126.

28. de Moya EA, García R. Three decades of male sex work in Santo Domingo. In: Aggleton P, ed. Men who sell sex: international perspectives on male prostitution and HIV/AIDS. Philadelphia: Temple University Press; 1999. Pp. 127-140.

29. Schifter J. Lila's house: male prostitution in Latin America. New York: Harrington Park Press-Haworth Press; 1998.

30. Schifter J, Aggleton P. Cacherismo in a San José brothel: aspects of male sex work in Costa Rica. In: Aggleton P, ed. Men who sell sex: international perspectives on male prostitution and HIV/AIDS. Philadelphia: Temple University Press; 1999. Pp. 141-158.

31. Cáceres CF, Jiménez OG. Fletes in Parque Kennedy: sexual cultures among young men who sell sex to other men in Lima. In: Aggleton $\mathrm{P}$, ed. Men who sell sex: international perspectives on male prostitution and HIV/ AIDS. Philadelphia: Temple University Press; 1999. Pp. 179-194.

32. Perlongher NO. La incidencia del abandono familiar en la prostitución homosexual masculina. In: Pérez Álvarez S, Perlongher NO, Sal Llarguez R, eds. La familia abandónica y sus consecuencias. Buenos Aires: EUDEBACEA Press; 1981.

33. Kornblit AL. Las personas afectadas por prácticas homosexuales. In: Kornblit AL, Medes Diz AM, Petracci M, Pecheny M, Vujosevich J, Giménez L, et al., eds. SIDA: entre el cuidado y el riesgo. Estudios en población general y en personas afectadas. Buenos Aires: Alianza Press; 2000. Pp. 239-291.

34. Pan American Health Organization. Regional Core Health Data System - country health profile 2001: Argentina [Internet site]. Available at: http://www.paho.org/English/SHA/ prflARG.htm. Accessed 15 March 2003.

35. Argentina, Instituto Nacional de Estadísticas y Censos. Población por sexo e índice de masculinidad. Total del país según región y provincia. Años 1991-2001 [Internet site]. Avail- 
able at: http://www.indec.mecon.ar/glosario/ poblacion.xls. Accessed 15 March 2003.

36. Código Penal (1984/1995). Título III. Delitos contra la honestidad. Buenos Aires: A-Z Editora; 1984.

37. Pecheny M. Los jóvenes, el VIH/SIDA y los derechos humanos: una reflexión sobre las experiencias en Argentina y en América Latina. In: Kornblit AL, Medes Diz AM, Petracci M, Pecheny M, Vujosevich J, Giménez L, et al., eds. SIDA: entre el cuidado y el riesgo. Estudios en población general y en personas afectadas. Buenos Aires: Alianza Press; 2000. Pp. 413-438.

38. Kornblit AL, Giménez L, Medes Diz AM, Vujosevich J. Y el SIDA está entre nosotros. . . un estudio sobre actitudes, creencias y conductas de grupos golpeados por la enfermedad. Buenos Aires: Ediciones Corregidor; 1997.

39. United Nations Programme on HIV/AIDS. Argentina. Epidemiological fact sheets on HIV/ AIDS and sexually transmitted infections. 2002 update [Internet site]. Available at: http:// www.unaids.org. Accessed 15 October 2002.
40. Pan American Health Organization. AIDS surveillance in the Americas. Biannual report June 2002 [Internet site]. Available at: http:/ / www.paho.org/English/HCP/HCA/AIDS survJun02.pdf. Accessed 15 March 2003.

41. Sacco WP, Levine B, Reed DL, Thompson K. Attitudes about condom use as an AIDSrelevant behavior: their factor structure and relation to condom use. J Cons Clin Psychol 1991;3(2):265-272.

42. National Centre in HIV Social Research. Sydney Men and Sexual Health (SMASH) Study. Core questionnaire 1996 [Internet site]. Available at: http://www.bhs.mq.edu.au/nchsr/ coreques.html. Accessed August 1997.

43. Dolcini MM, Catania JA, Choi KH, Fullilove MT, Coates TJ. Cognitive and emotional assessment of perceived risk for HIV among unmarried heterosexuals. AIDS Educ Prev 1996; 8(4):294- 307.

44. Longshore D, Hsieh S, Anglin MD. AIDS knowledge and attitudes among injection drug users: the issue of reliability. AIDS Educ Prev 1992;4(1):29-40.
45. Wallston KA, Maides S, Wallston BS. Healthrelated information seeking as a function of health-related locus of control and health value. J Res Personality Soc 1976;10:215-222.

46. Pleak RR, Meyer-Bahlburg HFL. Sexual behavior and AIDS knowledge of young male prostitutes in Manhattan. J Sex Res 1990;27(2): 557-587.

47. Leigh BC. Alcohol consumption and sexual activity as reported with a diary technique. J Abnormal Psych 1993;102(3):490-493.

48. Sacket D. Bias in analytic research. J of Chronic Dis 1979;32(1/2):51-63.

49. Argentina, Programa Nacional de Lucha contra el SIDA y ETS. 1ro. de diciembre. Día mundial de lucha contra el SIDA. Campaña 2002-2003 [Internet site]. Available at: http:/ / www.msal.gov.ar/htm/site/Lusida/frIndex. htm. Accessed 15 March 2003.

Manuscript received 3 May 2002. Revised version accepted for publication on 2 January 2003

RESUMEN Objetivo. Informar acerca de las características sociodemográficas y las experiencias de 31 trabajadores sexuales masculinos (TSM) de la ciudad de Córdoba, Argentina.

Métodos. La información de cada uno de los TSM fue obtenida mediante un cues-

Trabajadores sexuales masculinos en Córdoba, Argentina: características sociodemográficas y experiencias en el trabajo sexual tionario que indagaba acerca de sus características personales, su actividad profesional, la percepción que tenían de su estado general de salud y el uso que hacían de los servicios sociales y de salud. Se establecieron escalas para evaluar la actitud de los encuestados acerca del uso de condones, sus conocimientos sobre el sexo seguro, la percepción que tenían acerca del riesgo de infectarse con el VIH, su grado de autorrealización y sus posibilidades de controlar las negociaciones con los clientes. El cuestionario también le pedía a cada encuestado que evaluara su grado de aceptación de las posibles estrategias para lograr la satisfacción del cliente mediante prácticas sexuales seguras.

Resultados. En términos de su autorreconocimiento, 10 de los 30 TSM que respondieron esa pregunta $(33,3 \%)$ se consideraban heterosexuales, mientras que 9 de ellos (30\%) se calificaban como bisexuales. El consumo de alcohol y drogas, así como las prácticas sexuales riesgosas eran relativamente poco frecuentes. De los 31 TSM encuestados, $21(67,7 \%)$ informaron que habían pasado pruebas para el VIH, pero solo 13 de ellos $(41,9 \%)$ manifestaron haber sido vacunados contra la hepatitis A o hepatitis B. Se observaron muy variadas respuestas entre los 17 TSM de la calle encuestados (aquellos que ofrecían sus servicios en lugares públicos, como calles y parques) y los 14 TSM independientes (los que se anunciaban, manejaban su propio negocio y tenían un lugar dedicado a su actividad de comercio sexual). Los TSM de la calle resultaron más jóvenes y tenían menos educación formal, mientras que los TSM independientes eran económicamente más solventes, habían trabajado por más tiempo en la industria del sexo y sentían menos reparos en tener relaciones sexuales con otros hombres. Además, los TSM eran más propensos a declarar su orientación homosexual y tenían menos inclinación al consumo de alcohol, marihuana u otras substancias de ese tipo. Conclusiones. Las diferencias encontradas entre los TSM de la calle y los independientes son importantes, ya que pueden explicar la posición que cada uno puede lograr en la negociación con sus clientes para ajustarse a prácticas sexuales seguras. Se deben establecer programas para la prevención de la diseminación del VIH y otras infecciones de transmisión sexual, así como para la promoción de actitudes responsables entre los TSM de Córdoba. Estos programas deben ayudar a aumentar la proporción de TSM que conocen su estado serológico con relación al VIH y podrían llevar a estas personas a cobrar mayor conciencia de los riesgos que entrañan las diferentes prácticas sexuales. Dadas las diferencias encontradas entre los TSM de la calle y los independientes, se deben desarrollar estrategias y materiales educativos específicos para cada uno de estos grupos. 